\title{
EHMTI-0011. Spinal manipulation for a child with chronic cervicogenic headaches: a case report
}

\author{
J Alcantara*, R Olsen \\ From 4th European Headache and Migraine Trust International Congress: EHMTIC 2014 \\ Copenhagen, Denmark. 18-21 September 2014
}

\section{Background}

Headaches are common in childhood and increases in frequency towards adolescence. Headache prevalence range from $37 \%$ to $51 \%$ in those $\leq 7$ years of age and increases to $57 \%$ to $82 \%$ by age 15 years. Prior to puberty, boys are affected more frequently than girls, but following the onset of puberty, headaches occur more frequently in girls. Many sufferers turn to alternative therapies to augment their medical care. In the interest of evidence-informed practice, we describe the chiropractic care of a child with chronic cervicogenic headaches.

\section{Clinical features}

A 6-year-old male with chronic headaches of 2 years duration presented for chiropractic care. No organic cause was determined by extensive medical diagnostics. Medical care consisted of ibuprofen which provided only minor relief.

\section{Intervention and outcome}

The child was cared for with chiropractic care characterized as high velocity, low amplitude thrust-type spinal manipulation directed to sights of segmental dysfunction in the cervical spine. The patient attended care for a total of 10 visits over a 2-month period with resolution of the patient's headache complaints.

\section{Conclusion}

This case report provides supporting evidence in the use of spinal manipulation in the care of children with cervicogenic headaches.

No conflict of interest.

The International Chiropractic Pediatric Association, San Francisco, USA
Published: 18 September 2014

doi:10.1186/1129-2377-15-S1-C2

Cite this article as: Alcantara and Olsen: EHMTI-0011. Spinal

manipulation for a child with chronic cervicogenic headaches: a case report. The Journal of Headache and Pain 2014 15(Suppl 1):C2.

\section{SpringerOpen ${ }^{\odot}$}

(C) 2014 Alcantara and Olsen; licensee Springer. This is an Open Access article distributed under the terms of the Creative Commons Attribution License (http://creativecommons.org/licenses/by/2.0), which permits unrestricted use, distribution, and reproduction in any medium, provided the original work is properly cited.
Submit your manuscript to a SpringerOpen ${ }^{\circ}$ journal and benefit from:

- Convenient online submission

- Rigorous peer review

- Immediate publication on acceptance

- Open access: articles freely available online

- High visibility within the field

Retaining the copyright to your article

Submit your next manuscript at $>$ springeropen.com 